\title{
PENGARUH RASIO DAN KINERJA KEUANGAN TERHADAP HARGA SAHAM PADA INDEKS LQ45 DI BURSA EFEK INDONESIA (BEI) PERIODE 2015-2016
}

\author{
I Nyoman Sutapa* \\ Fakultas Ekonomi Universitas Warmadewa, Denpasar, Bali \\ *E-Mail: sutapa05@ymail.com
}

DiPublikasi: 31/01/2018

DOI: $10.22225 / k r \cdot 9 \cdot 2 \cdot 467 \cdot 11-19$

Halaman: 11 - 19

\begin{abstract}
This study aims to test whether the ratio analysis consisting of Current Ratio (CR), Debt Equity Ratio (DER), Return on Equity (ROE), and Financial Performance consisting of Earning per share (EPS) have an effect on Stock Price. The population in this study is the company that entered in the index LQ45 in 2015-2016. The sampling technique used in this study is by purposive sampling where the sample is selected on the basis of certain considerations or criteria and the number of samples obtained in the study were 56 companies. The results showed that: (1) Current Ratio has a positive effect on stock prices. (2) .Debt to Equity Ratio does not affect the stock price. (3). Return on Equity does not affect the stock price (4). Earning per share has a positive effect on stock prices.
\end{abstract}

\section{Keywords: Current Ratio, Debt Equity Ratio, Return on Equity, Earning per share, Stock Price.}

\begin{abstract}
Abstrak
Penelitian ini bertujuan untuk menguji apakah analisis rasio yang terdiri dari Current Ratio (CR), Debt Equity Ratio (DER), Return on Equity (ROE), dan Kinerja Keuangan yang terdiri dari Earning per share (EPS) berpengaruh terhadap Harga Saham. Populasi dalam penelitian ini adalah perusahaan yang masuk dalam indeks LQ45 pada tahun 2015-2016. Teknik pengambilan sampel yang digunakan dalam penelitian ini adalah dengan purposive sampling dimana sampel dipilih atas dasar pertimbangan atau kriteria tertentu dan jumlah sampel yang didapat dalam penelitian adalah 56 perusahaan. Hasil penelitian menunjukkan bahwa : (1) Current Ratio berpengaruh positif terhadap harga saham. (2).Debt to Equity Ratio tidak berpengaruh terhadap harga saham. (3).Return on Equity tidak berpengaruh terhadap harga saham (4).Earning per share berpengaruh positif terhadap harga saham
\end{abstract}

\section{Kata kunci: Current Ratio, Debt Equity Ratio, Return on Equity, Earning per share, Harga saham.}

\section{PENDAHULUAN}

Menurut Husnan (2006) pasar modal adalah pasar untuk berbagai instrumen keuangan jangka panjang yang bisa diperjualbelikan, baik dalam bentuk hutang maupun modal sendiri. Baik yang diterbitkan oleh pemerintah maupun perusahaan swasta.

Salah satu jenis sekuritas yang paling populer di pasar modal adalah sekuritas saham. Pada umumnya, saham adalah suatu surat berharga yang menunjukkan adanya kepemilikan seseorang atau badan hukum terhadap perusahaan penerbit saham (Darmadji dan Fakhruddin, 2001). Pengertian lain, saham adalah tanda penyertaan atau pemilikan seseorang atau badan dalam suatu perusahaan (Fakhruddin dan Hadianto, 2001).
Kinerja keuangan suatu perusahaan merupakan salah satu cara yang dilakukan yaitu dengan analisis terhadap laporan keuangan. Analisis terhadap laporan keuangan suatu perusahaan pada dasarnya karena ingin mengetahui tingkat profitabilitas (keuntungan) dan tingkat resiko atau tingkat kesehatan suatu perusahaan. Analisis keuangan yang mencakup analisis rasio keuangan, analisis kelemahan dan kekuatan di bidang finansial akan sangat membantu dalam menilai prestasi manajemen masa lalu dan prospeknya di masa datang.

Laporan keuangan yang disusun secara baik dan akurat dapat memberikan gambaran keadaaan yang nyata mengenai hasil atau prestasi yang telah dicapai oleh suatu perusahaan selama kurun waktu tertentu, keadaan inilah yang digunakan untuk menilai kinerja 
keuangan. Apalagi informasi mengenai kinerja keuangan suatu perusahaan sangat bermanfaat untuk berbagai pihak seperti investor, kreditur, pemerintah, bankers, pihak manajemen sendiri dan pihak-pihak lain yang berkepentingan. Berdasarkan hal tersebut peneliti merumuskan rumusan masalah sebagai berikut:

1) Bagaimana pengaruh Current Ratio terhadap harga saham?

2) Bagaimana pengaruh Debt to Equity Ratio terhadap harga saham?

3) Bagaimana pengaruh Return on Equity terhadap harga saham?

4) Bagaimana pengaruh Earning per share terhadap harga saham?

\section{TINJAUAN PUSTAKA}

\section{A. Tinjauan Pustaka}

\section{Rasio Keuangan dan Manfaatnya}

Rasio keuangan digunakan untuk membandingkan risiko dan tingkat imbal hasil dari berbagai perusahaan untuk membantu investor dan kreditor membuat keputusan investasi dan kredit yang baik (White et al., 2002). Ada empat kategori rasio yang digunakan untuk mengukur berbagai aspek dari hubungan risiko dan return (White et al., 2002), yaitu sebagai berikut.

a) Analisis likuiditas: mengukur kecukupan sumber kas perusahaan untuk memenuhi kewajiban yang berkaitan dengan kas dalam jangka pendek.

b) Analisis solvency dan long term debt (leverage): menelaah struktur modal perusahaan, termasuk sumber dana jangka panjang dan kemampuan perusahaan untuk memenuhi kewajiban investasi dan utang jangka panjang.

c) Analisis aktivitas: mengevaluasi revenue dan output yang dihasilkan oleh aset perusahaan.

d) Analisis profitabilitas: mengukur earnings (laba) perusahaan relatif terhadap revenue (Pendapatan) dan modal yang diinvestasikan.

Salah satu tujuan dan keunggulan dari rasio adalah dapat digunakan untuk membandingkan hubungan return dan risiko dari perusahaan dengan ukuran yang berbeda. Rasio juga dapat menunjukkan profil suatu perusahaan, karakteristik ekonomi, strategi bersaing dan keunikan karakteristik operasi, keuangan dan investasi.

\section{Analisis Rasio Keuangan}

Analisis Rasio Keuangan Menurut Kasmir (2015:104) rasio keuangan merupakan kegiatan yang membandingkan angka-angka yang ada dalam laporan keuangan dengan cara membagi suatu angka dengan angka lainnya. Perbandingan dapat dilakukan antara suatu komponen dengan komponen dalam satu laporan keuangan atau antara komponen yang ada diantara laporan keuangan, kemudian angka yang diperbandingkan dapat berupa angkaangka dalam satu periode maupun beberapa periode.

\section{Jenis-jenis Rasio Keuangan}

Menurut Kasmir (2015:110-208) analisis rasio yang dapat digunakan dalam penilaian kinerja keuangan perusahaan meliputi:

\section{Rasio Likuiditas}

Adalah rasio yang digunakan untuk menunjukkan atau mengukur kemampuan perusahaan dalam memenuhi kewajibannya yang jatuh tempo, baik kewajiban kepada pihak luar perusahaan maupun di dalam perusahaan. Dengan kata lain rasio likuiditas menunjukkan kemampuan perusahaan untuk membayar utang-utang (kewajiban) jangka pendeknya yang jatuh tempo atau rasio yang digunakan untuk mengetahui kemampuan perusahaan dalam membiayai dan memenuhi kewajiban (utang) pada saat ditagih. Jenis rasio likuiditas yang digunakan yaitu:

Current Ratio (Rasio Lancar) Rasio yang digunakan untuk mengukur kemampuan perusahaan dalam membayar kewajiban jangka pendeknya atau utang yang segera jatuh tempo pada saat ditagih secara keseluruhan. Dengan kata lain, seberapa banyak aktiva lancar yang tersedia untuk menutupi kewajiban jangka pendek segera jatuh tempo, atau dapat dikatakan sebagai bentuk untuk mengukur tingkat keamanan suatu perusahaan. Semakin tinggi nilai Current Ratio berarti semakin besar kemampuan perusahaan untuk memenuhi kewajiban jangka pendeknya. Untuk menghitung Current Ratio menggunakan rumus:

$$
\text { Current Ratio }=\frac{\text { Aktiva Lancar }}{\text { Utang Lancar }}
$$

\section{Rasio Solvabilitas (Leverage)}

Adalah rasio yang digunakan untuk menunjukkan atau mengukur sejauh mana aktiva perusahaan dibiayai dengan utang atau dengan kata lain berapa besar beban utang yang ditanggung perusahaan dibandingkan dengan aktivanya. Dalam arti luas dikatakan bahwa rasio ini digunakan untuk mengukur kemampuan perusahaan untuk membayar seluruh kewajibannya, baik jangka pendek maupun jangka panjang apabila perusahaan dilikuidasi (dibubarkan). Jenis-jenis rasio solvabilitas meliputi:

a) Debt to Asset Ratio / DAR (Rasio Hutang Terhadap Total Aktiva) Adalah rasio yang digunakan untuk mengukur perbandingan anta- 
ra total utang dengan total aktiva. Dari hasil pengukuran, apabila rasionya tinggi maka pendanaan dengan utang semakin banyak yang artinya semakin sulit bagi perusahaan untuk memperoleh tambahan pinjaman karena dikhawatirkan perusahaan tidak mampu menutupi utang-utangnya dengan aktiva yang dimilikinya. Demikian pula bila rasionya rendah maka semakin kecil perusahaan dibiayai dengan utang. Untuk menghitung debt to asset ratio menggunakan rumus:

$$
\text { Debt to Asset Ratio }=\frac{\text { Total Utang }}{\text { Total Aktiva }}
$$

b) Debt to Equity Ratio/ DER (Rasio Hutang Terhadap Ekuitas) Adalah rasio yang digunakan untuk menilai utang dengan ekuitas dan berfungsi untuk mengetahui setiap modal sendiri yang dijadikan untuk jaminan utang. Rasio ini dicari dengan membandingkan antara seluruh utang, termasuk utang lancar dengan seluruh ekuitas. Bagi bank, semakin besar rasio ini akan semakin tidak menguntungkan karena akan semakin besar resiko yang ditanggung atas kegagalan yang mungkin terjadi di perusahaan dan bagi perusahaan justru semakin besar rasio akan semakin baik. Sebaliknya, rasio yang rendah akan semakin tinggi tingkat pendanaan yang disediakan pemilik dan semakin besar batas pengamanan bagi peminjam jika terjadi kerugian atau penyusutan terhadap nilai aktiva. Untuk menghitung Debt to Equity Ratio menggunakan rumus:

$$
\text { Debt to Equity Ratio }=\frac{\text { Total Utang }}{\text { Ekuitas }}
$$

\section{Rasio Profitabilitas}

Adalah rasio yang digunakan untuk menilai kemampuan perusahaan dalam mencari keuntungan. Tujuannya adalah agar terlihat perkembangan perusahaan dalam rentang waktu tertentu, baik penurunan atau kenaikan dan sekaligus mencari penyebab perubahan tersebut. Pada prinsipnya, semakin tinggi profitabilitas perusahaan dalam pemperoleh laba maka semakin baik dan perusahaan mampu menggunakan aktivanya secara produktif. Jenis rasio profitabilitas yang digunakan yaitu:

Return on Equity (ROE) Adalah rasio yang digunakan untuk mengukur kemampuan perusahaan menghasilkan laba bersih berdasarkan modal saham tertentu, rasio ini merupakan ukuran profitabilitas dari sudut pandang pemegang saham. Rasio yang tinggi menunjukkan kemampuan modal sendiri yang dimiliki perusahaan untuk menghasilkan laba baik. Untuk menghitung Return on Equity menggunakan rumus:

Return On Equity $=\frac{\text { Laba bersih setelah pajak (EAT) }}{\text { Modal Sendiri }}$

\section{Rasio Nilai Pasar}

Menurut Fahmi (2012:70) rasio nilai pasar yaitu rasio yang menggambarkan kondisi yang terjadi di pasar. Rasio ini juga sering dipakai untuk melihat bagaimana kondisi perolehan keuntungan yang potensial dari suatu perusahaan, jika keputusan menempatkan dana di perusahaan tersebut terutama untuk masa yang akan datang. Menurut Fahmi (2012:138) jenis rasio nilai pasar yang digunakan oleh perusahaan yaitu: Earning per share / EPS (Pendapatan per Saham) Earning per share atau pendapatan per saham adalah bentuk pemberian keuntungan yang diberikan kepada para pemegang saham dari setiap lembar saham yang dimiliki. Rumus untuk menghitung EPS suatu perusahaan adalah sebagai berikut:

$$
\text { Earning Per Share }=\frac{\text { Laba Bersih Setelah Pajak }(\text { EAT })}{\text { Jumlah saham beredar }}
$$

\section{Harga Saham}

Dipergunakannya saham sebagai salah satu alat untuk mencari tambahan dana menyebabkan kajian dan analisis tentang saham begitu berkembang baik secara fundamental dan teknikal. Berbagai literatur mencoba memberikan rekomendasi yang berbedabeda namun tujuannya sama yaitu ingin memberikan profit yang tinggi bagi pemakainya, serta memiliki dampak keputusan yang bersifat berkelanjutan. Menurut Fahmi (2015 : 270) mengemukakan bahwa saham adalah:

a) Tanda bukti penyertaan kepemilikan modal/ dana pada suatu perusahaan.

b) Kertas yang tercantum dengan jelas nilai nominal, nama perusahaan dan diikuti dengan hak dan kewajiban yang dijelaskan kepada setiap pemegangnya.

c) Persediaan yang siap untuk di jual.

\section{Indeks Harga Saham}

Keputusan investor memilih suatu saham sebagai obyek investasinya membutuhkan data historis terhadap pergerakan saham yang beredar di bursa baik secara individual, kelompok, maupun gabungan. Setiap investor yang melakukan investasi saham memiliki tujuan yang sama, yaitu mencari keuntungan atas investasi tersebut. Salah satu keuntungan investasi saham yaitu mendapatkan capital gain yang berasal dari selisih harga saat membeli saham dengan harga saat menjual saham, dimana harga saham saat dijual lebih tinggi dibanding harga saham saat dibeli. Menurut Sunariyah (2011: 136 ) harga saham merupakan satuan angka dasar yang telah di sepakati. Harga saham dipengaruhi oleh permintaan dan penawaran terhadap saham itu sendiri di pasar, sehingga harga saham memiliki keterkaitan dengan pasar suatu saham. Semakin banyak investor yang ingin membeli saham suatu perus- 
ahaan (permintaan), sedangkan sedikit investor yang ingin menjual saham tersebut (penawaran) maka harga saham tersebut akan semakin turun.

\section{B. Hipotesis Penelitian}

\section{Pengaruh Current Ratio (CR) Terhadap Har- ga Saham}

Perusahaan yang memiliki likuiditas baik maka memungkinkan pembayaran deviden dengan lebih baik pula (Gitman 2009). Pembayaran deviden yang lebih baik maka investor akan tertarik menanamkan investasi di perusahaan tersebut, dengan meningkatnya permintaan saham dari para investor maka akan mempengaruhi harga saham. Jeany Clarensia, Sri Rahayu dan Nur Azizah (2012) meneliti tentang pengaruh likuiditas terhadap harga saham dengan hasil penelitiannya menyatakan bahwa Current Ratio berpengaruh terhadap harga saham. Berdasarkan tinjauan pustaka, penelitian terdahulu yang dilakukan dan kerangka pemikian di atas, maka dapat diajukan sebuah hipotesis sebagai berikut.

$\mathrm{H}_{1}$ : Current Ratio berpengaruh positif terhadap Harga Saham

\section{Pengaruh Debt to Equity Ratio (DER) Terhadap Harga Saham}

Semakin tinggi DER menunjukkan semakin rentan terhadap fluktuasi kondisi perekonomian. Pada kondisi ekonomi yang tidak normal, perusahaan mungkin akan mengalami penurunan penjualan sementara biaya-biaya mengalami kenaikan sehingga tingkat pengembalian atas aktiva menurun. Kerugian akan memberikan tekanan pada pergerakan harga saham dan pada akhirnya terjadi penurunan harga saham. Paramitha Idi Putri (2012) dalam penelitiannya tentang pengaruh Debt to Equity Ratio terhadap harga saham juga menyebutkan bahwa Debt to Equity Ratio berpengaruh signifikan terhadap harga saham. Berdasarkan tinjauan pustaka, penelitian terdahulu yang dilakukan dan kerangka pemikiran maka dapat diajukan sebuah hipotesis sebagai berikut.

$\mathrm{H}_{2}$ : Debt to Equity Ratio berpengaruh positif terhadap Harga Saham

\section{Pengaruh Return on Equity (ROE) Terhadap Harga Saham}

Return on Equity (ROE) adalah rasio yang menunjukkan kemampuan perusahaan dalam menghasilkan laba bersih untuk pengembalian ekuitas pemegang saham dan merupakan rasio yang digunakan untuk mengukur tingkat profitabilitas dari ekuitas (Munawir, 2002:90). Return on Equity (ROE) dapat memberikan gambaran tentang sejauh mana kemampuan perusahaan menghasilkan laba yang bisa diperoleh pemegang saham atas modal yang mereka investasikan di dalam perusahaan. ROE yang tinggi menunjukkan perusahaan mampu menggunakan ekuitasnya dengan efisien dan efektif, sehingga para investor percaya dan selanjutnya perusahaan mampu memberikan pendapatan yang lebih besar pula kepada pemegang saham. Dengan demikian semakin tinggi return yang diterima pemilik perusahaan akan semakin tinggi pula harga saham perusahaan yang bersangkutan. Sehingga dapat disimpulkan hubungan antara ROE dan harga saham merupakan hubungan positif. Penelitian tersebut juga mendukung penelitian oleh Anita (2007) bahwa variabel yang dipilih yaitu CAR, EPS, NPM, ROA, BOPO, dan DER. Secara simultan atau bersamasama antara CAR, RORA, dan LDR berpebgaruh secara signifikan terhadap perubahan harga saham perusahaan perbankan di BEJ sedangkan untuk ROA dan NPM dan BOPO tidak berpengaruh secara signifikan terhadap perubahan harga saham perusahaan perbankan di Bursa Efek Jakarta (BEJ)

$\mathrm{H}_{3}$ : Return on Equity berpengaruh positif terhadap Harga Saham

\section{Pengaruh Earning per share (EPS) Terhadap Harga Saham}

Menurut Syamsudin (2009:66) menyatakan bahwa pada umumnya investor tetarik pada Earning per share yang besar, karena hal ini merupakan salah satu indikator keberhasilan suatu perusahaan. Dengan demikian semakin tinggi nilai EPS perusahaan maka semakin tinggi pula laba yang akan dibagikan kepada pemegang saham dan akan semakin tinggi pula harga saham perusahaan yang bersangkutan. Penelitian tersebut juga mendukung penelitian oleh Rowland BFP (2008) menyatakan bahwa dengan hasil penelitian yaitu secara simultan semua variabel mempunyai pengaruh yang signifikan terhadap perubahan harga saham.

$\mathrm{H}_{4}$ : Earning per share berpengaruh positif terhadap Harga Saham

\section{III.METODELOGI PENELITIAN}

\section{Metode Pengumpulan Data}

Data merupakan data sekunder yang didapat dari mengunduh laporan keuangan melalui www.idx.co.id pada tahun amatan 2015 - 2016. Populasi pada penelitian ini adalah perusahaan yang publish di IDX yang terindeks LQ 45, Pemilihan sampel penelitian didasarkan pada metoda purposive sampling. berikut adalah kriteria purposive sampling adalah sebagai berikut:

a) Perusahaan yang terdaftar pada BEI yang masuk index LQ 45 periode 2015 sampai dengan 2016

b) Memilik data rasio keuangan 


\section{Definisi Operasional Variabel \\ Current Ratio (CR) \\ Current Ratio (Rasio Lancar) Rasio yang digunakan untuk mengukur kemampuan perusahaan dalam membayar kewajiban jangka pendeknya atau utang yang segera jatuh tempo pada saat ditagih \\ Harga Saham (HS) \\ Fahmi (2015) Saham adalah Tanda bukti penyertaan kepemilikan modal/dana pada suatu perusahaan. Dalam penelitian ini pengukuran harga saham dengan melihat harga closing price atau harga pe- nutupan} secara keseluruhan. Pengukuran variabel ini dapat dituliskan sebagai berikut:

$$
\text { Current Ratio }=\frac{\text { Aktiva Lancar }}{\text { Utang Lancar }}
$$

Debt to Equity Ratio (DER)

Adalah rasio yang digunakan untuk menilai utang dengan ekuitas dan berfungsi untuk mengetahui setiap modal sendiri yang dijadikan untuk jaminan utang. Atau dapat dituliskan sebagai berikut:

$$
\text { Debt to Equity Ratio }=\frac{\text { Total Utang }}{\text { Ekuitas }}
$$

Return on Equity (ROE)

Return on Equity (ROE) Adalah rasio yang digunakan untuk mengukur kemampuan perusahaan menghasilkan laba bersih berdasarkan modal saham tertentu, rasio ini merupakan ukuran profitabilitas dari sudut pandang pemegang saham. Pengukuran variabel ini dapat dituliskan sebagai berikut:

Return On Equity $=\frac{\text { Laba bersih setelah pajak (EAT) }}{\text { Modal Sendiri }}$ Earning per share (EPS)

Earning per share atau pendapatan per saham adalah bentuk pemberian keuntungan yang diberikan kepada para pemegang saham dari setiap lembar saham yang dimiliki. Rumus untuk menghitung EPS suatu perusahaan adalah sebagai berikut:

Earning Per Share $=\frac{\text { Laba Bersih Setelah Pajak (EAT) }}{\text { Jumlah saham beredar }}$

\section{Teknik Analisis Data}

Pada penelitian ini menggunakan Uji Regresi linear berganda dengan model sebagai berikut $\mathrm{HS}=\mathrm{a}+\beta 1 \mathrm{CR}+\beta 2 \mathrm{DER}+\beta 3 \mathrm{ROE}+\beta 4 \mathrm{EPS}+\mathrm{e}$

Keterangan:

$$
\text { HS = Harga Saham }
$$$$
\mathrm{CR}=\text { Current Ratio }
$$$$
\text { DER = Debt to Equity Ratio }
$$$$
\text { ROE = Return on Equity }
$$

$\mathrm{EPS}=\quad$ Earning per share

$$
\begin{array}{ll}
\mathrm{a} & =\text { Constanta } \\
\beta & =\text { Koefisien regresi } \\
\mathrm{e} & =\text { Error }
\end{array}
$$

\section{Populasi dan Sampel}

Populasi pada perusahaan manufaktur yang terdaftar di Bursa Efek Indonesia pada tahun 2015 sampai dengan 2016. Metode pemilihan sampel menggunakan metode purposive sampling. berikut total sampel setelah menggunakan purposive sampling. Berdasarkan tabel 1 total sampel pada penelitian ini adalah sebesar 56 dengan dua tahun amatan.

Tabel 1

Pengambilan Sampel Penelitian

\begin{tabular}{lcc}
\hline \multicolumn{1}{c}{ Kriteria Pengambilan Sampel } & Jumlah & $\begin{array}{c}\text { Sampel yang } \\
\text { dikeluarkan }\end{array}$ \\
\hline $\begin{array}{l}\text { Perusahaan yang terdaftar pada BEI yang masuk index LQ 45 periode } \\
\text { 2015 sampai dengan 2016 }\end{array}$ & 40 & \\
\hline Memilik data rasio keuangan & 28 & 12 \\
\hline Jumlah Perusahaan yang menjadi sampel & 28 \\
\hline Jumlah total Pengamatan (2 tahun amatan) & 56 \\
\hline
\end{tabular}

Sumber: data diolah 2017 


\section{IV.HASIL PENELITIAN DAN PEMBAHASAN}

\section{Statistik Deskriptif}

Pada tabel 2 membahas mengenai statistik deskriptif. Dalam tabel tersebut disajikan mengenai nilai minimum, maksimum, mean dan standar

Tabel 2

Statistik Deskriptif

\begin{tabular}{|c|c|c|c|c|c|}
\hline Variabel & $\mathrm{N}$ & Minimum & Maximum & Mean & Std. Deviation \\
\hline Current Ratio & 56 & $-0,33$ & 6,61 & 4,9396 & 1,15656 \\
\hline Debt to Equity Ratio & 56 & $-2,04$ & 0,99 & $-0,3163$ & 0,75852 \\
\hline Return on Equity & 56 & $-2,30$ & 5,08 & 2,5084 & 1,12319 \\
\hline Earning per share & 56 & 0,00 & 8,15 & 5,1264 & 1,68109 \\
\hline Harga saham & 56 & 5,84 & 11,07 & 8,4250 & 1,23280 \\
\hline Valid N (listwise) & & & & & \\
\hline
\end{tabular}

Sumber : data diolah 2017
2. Hasil Pengujian Asumsi Klasik

a) Uji Normalitas

Berdasarkan hasil test one-sample Kolmogorov- deviasi. Setelah dilakukan winsorizing untuk variabel yang outlier yaitu variabel yang berada diluar range dari means \pm 3 kali dari standar deviasi untuk masing -masing variabel (Beatty et.al.2003)

\section{Tabel 3}

Uji Normalitas

\begin{tabular}{ll}
\hline \multicolumn{1}{c}{ Persamaan Regresi } & $\begin{array}{l}\text { Asymp. Sig. (2- } \\
\text { tailed) }\end{array}$ \\
\hline $\mathrm{HS}=\mathrm{a}+\beta 1 \mathrm{CR}+\beta 2 \mathrm{DER}+\beta 3 \mathrm{ROE}+\beta 4 \mathrm{EPS}+\mathrm{e}$ & 0,200 \\
\hline Sumber $:$ data diolah 2017 &
\end{tabular}

\section{b) Uji Multikolinearitas}

Berdasarkan hasil olah data, nilai VIF $<10$. Dapat disimpulkan data tersebut tidak terjadi gejala multikoliniearitas.

Tabel 4

Uji Multikoliniearitas

\begin{tabular}{lcl}
\hline Variabel & Tolerance & VIF \\
\hline Current Ratio &, 755 & 1,324 \\
Debt to Equity &, 703 & 1,423 \\
Ratio & & \\
Return on Equity &, 634 & 1,578 \\
Earning per share &, 660 & 1,515 \\
\hline
\end{tabular}

\section{c) Uji autokorelasi}

Berdasarkan hasil olah data, nilai DW sebesar 1,874 lebih besar dari batas (du) sebesar 1.7678 dan lebih kecil dari (4-du) sebesar 2.2322 dapat smirnor sebesar 0,200 lebih besar dari nilai $\mathrm{Sig}>$ 0,05 dapat disimpulkan bahwa data pada model terdistribusi secara normal.
Sumber : data diolah 2017

disimpulkan bahwa data pada model tidak terdapat autokorelasi seperti terlihat pada tabel 4 Uji autokorelasi model 
Tabel 5

Uji Autokorelasi

\begin{tabular}{cc}
\hline Model & Durbin-Watson \\
\hline $\mathrm{HS}=\mathrm{a}+\beta 1 \mathrm{CR}+\beta 2 \mathrm{DER}+\beta 3 \mathrm{ROE}+\beta 4 \mathrm{EPS}+\mathrm{e}$ & 1,874 \\
\hline
\end{tabular}

\section{Sumber: data diolah 2017}

\section{d) Uji heterokedastisitas}

Berdasarkan hasil olah data pada tabel 5 dapat disimpulkan bahwa data pada model tidak terdapat gejala heterokedatisitas yang tercermin dari signifikansi ukuran perusahaan, kompensasi dan leverage diatas alfa yaitu $5 \%(0,05)$

Tabel 6

Uji heterokedastisitas

\begin{tabular}{lr}
\hline \multicolumn{1}{c}{ Variabel } & Sig \\
\hline Current Ratio & 0,244 \\
Debt to Equity Ratio & 0,158 \\
Return on Equity & 0,609 \\
Earning per share & 0,052 \\
\hline Sumber : data diolah 2017 &
\end{tabular}

\section{Pembahasan}

\section{1) Pengaruh Current Ratio terhadap harga} saham

Berdasarkan pada tabel 6 dapat ditarik kesimpulan bahwa Current Ratio digunakan untuk mengukur kemampuan perusahaan dalam membayar kewajiban jangka pendeknya atau utang yang segera jatuh tempo pada saat ditagih secara keseluruhan. Dengan kata lain, seberapa banyak aktiva lancar yang tersedia untuk menutupi kewajiban jangka pendek segera jatuh tempo, atau dapat dikatakan sebagai bentuk untuk mengukur tingkat keamanan suatu perusahaan. Semakin tinggi nilai Current Ratio berarti semakin besar kemampuan perusahaan untuk memenuhi kewajiban jangka pendeknya. (Kasmir, 2015:110). Hal ini menunjukkan bahwa semakin tinggi Current Ratio maka semakin tinggi harga saham. Sebaliknya juga jika semakin rendah Current Ratio maka semakin rendah harga saham. Hasil penelitian ini sejalan dengan Amanah et.al (2014), Wuryaningrum (2015), dan Sudirjo (2016)

\section{2) Pengaruh Debt to Equity Ratio terhadap harga saham}

Berdasarkan pada tabel 6 dapat ditarik kesimpulan bahwa Debt to Equity Ratio pengaruhnya tidak signifikan terhadap harga saham hal ini dikarenakan DER yang tinggi dipandang oleh sebagian investor sebagai suatu hal yang wajar, perusahaan yang tumbuh pasti akan memerlukan banyak dana operasional yang tidak mungkin dipenuhi hanya dari modal sendiri yang dimiliki perusahaan (Kasmir, 2015:157) hasil penelitian ini serupa dengan penelitian Wuryaningrum (2015)

\section{3) Pengaruh Return on Equity terhadap harga saham}

Berdasarkan pada tabel 6 dapat ditarik kesimpulan bahwa Return on Equity pengaruhnya tidak signifikan terhadap harga saham. ROE, tidak berpengaruh signifikan terhadap harga saham yang terdaftar di Bursa Efek Indonesia pada indeks LQ45. Hal ini terjadi karena ternyata laba perusahaan yang menjadi salah satu indikator perhitungan ROE bukanlah satusatunya indikator dalam pengambilan keputusan harga saham. Biaya modal juga sangat dipengaruhi oleh tingkat suku.bunga.

\section{4) Pengaruh Earning per share terhadap harga saham}

Earning per share (EPS) merupakan rasio yang banyak diperhatikan oleh calon investor, karena informasi EPS merupakan informasi yang dianggap paling mendasar dan berguna yang dapat menggambarkan prospek earning perusahaan dimasa yang akan datang. Perhitungan EPS pada dasarnya mempunyai tujuan untuk melihat kemajuan dari operasi perusahaan, untuk menentukan harga saham dan besarnya deviden yang akan dibagikan. Menurut Syamsudin (2009:66) menyatakan bahwa pada umumnya investor tetarik pada Earning per share yang besar, karena hal ini merupakan salah satu indikator keberhasilan suatu perusahaan. Dengan demikian semakin tinggi nilai EPS perusahaan maka semakin tinggi pula laba yang akan dibagikan kepada pemegang saham dan akan semakin tinggi pula harga saham perusahaan yang bersangkutan. 
Tabel 7

Uji Hipotesis

\begin{tabular}{llll}
\hline \multicolumn{1}{c}{ Variabel } & B & T & Sig \\
\hline (Constant) & 4,499 & 7,700 &, 000 \\
\hline Current Ratio &, 243 & 2,312 &, 025 \\
\hline $\begin{array}{l}\text { Debt to Equity } \\
\text { Ratio }\end{array}$ &, 179 & 1,079 &, 286 \\
\hline $\begin{array}{l}\text { Return on Equity } \\
\text { Earning per }\end{array}$ &,- 045 &,- 380 &, 706 \\
share &, 565 & 7,299 &, 000 \\
\hline $\begin{array}{l}\text { Adjusted R Square } \\
\text { F }=0,625\end{array}$ & & \\
$\mathrm{~F}=21,285$ & & \\
sig $\mathrm{F}=0,000$ & & \\
\hline
\end{tabular}

Sumber : data diolah 2017

\section{KESIMPULAN}

Berikut adalah kesimpulan yang dapat peneliti rangkum adalah.

1) Current Ratio berpengaruh positif terhadap harga saham.

2) Debt to Equity Ratio tidak berpengaruh terhadap harga saham.

3) Return on Equity tidak berpengaruh terhadap harga saham.

4) Earning per share berpengaruh positif terhadap harga saham

\section{VI.SARAN}

Saran bagi peneliti selanjutnya agar memperluas variabel rasio keuangan lainnya karena peneliti menemukan beberapa variabel yang terdapat gejala multikoliniearitas sehingga peneliti memutuskan menghapus beberapa variabel tersebut yaitu Debt to asset ratio dan Return on asset. Peneliti selanjutnya diharapkan bisa meneliti variabel tersebut atau menggunakan variabel rasio lainnya yang lebih banyak digunakan pada tahun yang terbaru.

\section{DAFTAR PUSTAKA}

Amanah, R., D. Atmanto., dan D.F. Azizah. 2014. Pengaruh Rasio Likuiditas dan Rasio Profitabilitas Terhadap Harga Saham. Jurnal Administrasi Bisnis (JAB) 12(1): 1-10.

Beatty, A., dan Weber, J. (2003). The effect of Debt Contracting on Voluntary Accounting Method Changes. Journal Accounting Review. Pp.119 142.

Darmadji, Tjiptono dan Hendy M. Fakhruddin. 2001. Pasar Modal di Indonesia. Jakarta: Salemba Empat.

Darmadji, Tjiptono dan Hendy M. Fakhruddin.
2001. Pasar Modal di Indonesia. Jakarta: Salemba Empat.

Fahmi, Irham. 2015. Pengantar Manajemen Keuangan. Penerbit ALFABETA: Bandung.

Ghozali, Imam. 2011. Analisis Multivariate Lanjutan dengan Program SPSS. Semarang: Badan Penerbit Universitas Diponegoro.

Gitman, Lawrence J. 2009. "Principles of Managerial Finance". Twelfth Edition. Prentice Hall.

Husnan, Suad dan Enny Pudjiastuti. 2006. DasarDasar Manajemen Keuangan. Edisi Kelima. UPP STIM YKPN. Yogyakarta

Jeany, Clarensia Sri Rahayu dan Nur Azizah, 2012. "Pengaruh Likuiditas, Profitabilitas, Pertumbuhan Penjualan, Dan Kebijakan Dividen Terhadap Harga Saham”. Universitas Budi Luhur, Jakarta.

Kasmir. 2015. Analisis Laporan Keuangan. PT. Raja Grafindo Persada. Jakarta.

Ria, Nofrita. 2013 "Pengaruh Profitabilitas Terhadap Nilai Perusahaan Dengan Kebijakan Deviden Sebagai Variabel Intervening (Studi Empiris pada Perusahaan Manufaktur Yang Terdaftar di BEI)", Universitas Negeri Padang, Padang

Riyanto, Bambang. 2000. "Dasar-dasar Pembelanjaan Perusahaan". Edisi Keempat, Yogyakarta, BPFE2000

Rowland, B.F.P. 2008. "Pengaruh Variabel Fundamental Terhadap Harga Saham Perusahaan Go Public di BEI". Jurnal Ekonomi dan Bisnis, Volume 2. Nomor 2. (101-113). ISSN : 1978-3116.

Sudirjo. 2016. "Pengaruh Analisis Rasio Keuangan, Rasio Pasar dan Kebijakan Deviden Terhadap Harga Saham" jurnal ilmiah UNTAG Semarang, ISSN : 2302-2752, Vol. 5 No.2, 2016 
Sunariyah. 2011. Pengantar Pengetahuan Pasar Modal. Penerbit UNIT PENERBIT \& PERCETAKAN: Yogyakarta.

Syamsudin, Lukman. 2009. Manajemen Keuangan Perusahaan. Jakarta : PT Raja Grafindo Persada.

Tiara, Rachma Putri. 2011. "Analisis Pengaruh Kinerja Keuangan Terhadap Harga Saham Pada Perusahaan Manufaktur Di Bursa Efek Indonesia" Fakultas Ekonomi, Universitas Gunadarma.

White G.I., Ashwinpaul C. Sondhi dan Dov Fried. 2002. The Analysis and Use of Financial Statements. USA: John Wiley. pg. 119-135.
Wuryaningrum. 2015. "Pengaruh Rasio Keuangan Terhadap Harga Saham Pada Perusahaan Farmasi di BEI". Jurnal Ilmu dan Riset Manajemen Volume 4, Nomor 11, November 2015

Zulfikar Jakaputera Djalamang, "Analisis Pengaruh Kinerja Keuangan Terhadap Harga Saham Pada Perusahaan Industri Makanan Minuman Yang Terdaftar Di Bursa Efek Indonesia (BEI”), Tompotika Luwuk. 